\title{
Pengaruh Ukuran Perusahaan terhadap Nilai Perusahaan dengan Moderasi Komite Audit
}

\author{
Rafika Sari $^{1)}$, Muhammad Hamdan Sayadi ${ }^{2)}$ \\ 1), 2) Program Studi Akuntansi Fakultas Ekonomi, Universitas Indo Global Mandiri, Palembang \\ Email: rafikasari@uigm.ac.id ${ }^{1}$, ${\text { hamdansayadi@uigm.ac.id }{ }^{2}}^{2}$
}

\begin{abstract}
ABSTRAK
Tujuan dari penelitian ini adalah untuk mengetahui Pengaruh Ukuran Perusahaan Terhadap nilai perusahaan pada perusahaan yang terdaftar di Bursa Efek Indonesia (BEI) selama periode 2016 dan bagaimana pengaruhnya jika ada moderasi dari jumlah komite audit. Penelitian ini menghubungkan hubungan antara variabel-variabel ini dan mengujinya secara empiris.Hasil penelitian menunjukan adanya hubungan antara aspek ekonomi dalam suatu perusahaan terhadap nilai perusahaan, baik secara parsial maupun simultan Metode analisis data yang digunakan adalah regresi linier. Metode ini dipilih karena referensi menunjukan bahwa adanya kecocokan antara alat analisis dengan variabel yang diteliti.Sampel pada penelitian ini menggunakan random sampling dengan rumus solvin tingkat signifikan 5 persen sehingga jumlah sampel adalah 191 perusahaan yang diambil secara acak. Metode random sampling dipilih karena sesuai dengan metode analisis regresi. Hasil penelitian variabel ukuran perusahaan memiliki pengaruh postitif signifikan terhadap Nilai Perusahaan pada perusahaan yang terdaftar di Bursa Efek Indonesia. Variabel Jumlah Komite Audit (Audit Commite) mampu memoderasi pengaruh ukuran perusahaan terhadap Nilai Perusahaan (Price Earning Rasio). Hasil penelitian ini mendukung pernyataan yang terdapat dalam teori agensi bahwa keberadaan komite audit memberikan eksternalitas positif bagi perusahaan dan mengurangi permasalahan konflik kepentingan dan memperkuat pengaruh ukuran perusahaan terhadap nilai perusahaan baik berdasarkan analisis simultan maupun berdasarkan analisis secara parsial.
\end{abstract}

Kata Kunci: Nilai, Ukuran, Moderasi Komite Audit

\section{Pendahuluan}

Di tengah persaingan global yang semakin ketat, perusahaan berlomba untuk meningkatkan daya saing di berbagai sektor untuk dapat menarik minat investor untuk berinvestasi. Oleh karena itu, nilai perusahaan menjadi sangat penting karena mencerminkan kinerja perusahaan yang dapat mempengaruhi persepsi investor terhadap perusahaan (Putri et al ,2016). Menurut (Susanto,Azhar.2013) peningkatan nilai perusahaan dapat memberikan sinyal positif kepada investor untuk berinvestasi pada suatu perusahaan.

Rasio Harga Pendapatan (Price Earning Ratio/PER) menggambarkan apresiasi pasar terhadap kemampuan perusahaan dalam menghasilkan pendapatan dimasa depan (Herlianto, 2013.) nilai perusahaan yang diukur dengan (Price Earning Ratio/PER) menggambarkan kondisi perusahaan kedepan .Ukuran perusahaan merupakan variabel yang berpotensi dan banyak digunakan untuk menjelaskan variasi minat bagi para investror untuk berinvestasi.

Hal ini jika dikaitkan dengan teori agensi, perusahaan besar yang memiliki biaya keagenan yang lebih besar namun biasanya menjadi pusat perhatian public dan menjadi target investor sehingga seharusnya memiliki nilai per yang tinggi pula Selain itu fenomena yang ada saat ini bahwa perusahaan yang besar menjadi sorotan baik oleh para investor maupun pemerintah bagaimana manajemen perusahaan mengelola usahanya, dengan struktur modal yang besar bagaimana dialokasikan untuk operasional perusahaan, (Kanwal et al., 2013). Ukuran Perusahaan Yang cenderung akan menarik minat investor karena akan berimbas dengan nilai perusahaan nantinya, sehingga dapat dikatakan bahwa besar kecilnya ukuran suatu perusahaan secara langsung berpengaruh terhadap nilai dari perusahaan tersebut.

Peneliti menggunakan kapitalisasi pasar sebagai indikator ukuran perusahaan karena kapitalisasi pasar ini menggambarkan potensi pertumbuhan perusahaan yang bagus serta memiliki resiko yang rendah (Japlani, 2015) sehingga kapitalisasi pasar dapat dijadikan suatu ukuran besar kecilnya perusahaan dari potensi pertumbuhan dan tingkat kepercayaan investor dalam menginvestasikan dana yang ada.

Kepemilikan saham merupakan faktor utama mekanisme good corporate governance yang berhak memegang kendali atas keputusan atau kebijakan yang akan dilakukan perusahaan. Mekanisme Corporate Governance tersebut meliputi banyak hal, contohnya jumlah dewan komisaris, independensi dewan komisaris, ukuran dewan direksi, dan keberadaan komite audit. Dengan adanya salah satu mekanisme GCG ini diharapkan dapat memonitoring manajer perusahaan lebih efektif sehingga dapat meningkatkan kinerja perusahaan dan nilai perusahaan.

Komite audit memiliki peran penting dalam menjaga akuntabilitas perusahaan. Komite audit bertugas mengawasi dan memantau sistem pelaporan keuangan perusahaan dan proses audit internal dan eksternal untuk menghindari asimetri informasi yang menjadi salah satu permasalahan dalam teori keagenan (Surjadi \& Tobing, 2016). 
Semakin banyak anggota dalam suatu komite audit akan mempengaruhi independensi dari komite audit. Oleh sebab itu semakin banyak anggota komite audit maka akan meningkatkan independensi komite audit dan akan berpengaruh terhadap kualitas laporan keuangan perusahaan . Dengan begitu Komite Audit diharapkan mampu meningkatkan nilai perusahaan dan membantu pelaksanaan Good Coporate Governance. Selain itu keberadaan dan independensi komite audit dapat mengurangi konflik kepentingan yang ada pada teori keagenan dan meningkatkan nilai perusahaan dimata principal (Anggraeini, 2012).

Peneliti menggunakan kapitalisasi pasar sebagai indikator ukuran perusahaan karena kapitalisasi pasar ini menggambarkan potensi pertumbuhan perusahaan yang bagus serta memiliki resiko yang rendah (Japlani, 2015) sehingga kapitalisasi pasar dapat dijadikan suatu ukuran besar kecilnya perusahaan dari potensi pertumbuhan dan tingkat kepercayaan investor dalam menginvestasikan dana yang ada.

Beberapa penelitian menurut (Puteuri \& Rohman, 2012) Ukuran perusahaan dinyatakan berhubungan positif dan signifikan terhadap nilai perusahaan. yang menyatakan bahwa ukuran perusahaan berpengaruh positif dan signifikan terhadap nilai perusahaan. Penelitian lain yang dilakukan oleh (Surjadi \& Tobing, 2016) menemukan bahwa ukuran perusahaan mempunyai nilai negatif dan signifikan terhadap nilai perusahaan.Penelitian yang dilakukan oleh ini memiliki hasil yang bertentangan, dimana hasil penelitian menyatakan bahwa ukuran perusahaan berpengaruh negatif dan signifikan terhadap nilai perusahaan.

Berdasarkan Fenomena yang ada dan adanya research gap dalam penelitian sejenis maka peneliti tertarik untuk mengadakan penelitian dengan judul: "Pengaruh Ukuran Perusahaan terhadap nilai perusahaan dengan moderasi dari jumlah komite audit. Adapun rumusan masalah dalam penelitian ini adalah (1) Bagaimana pengaruh Ukuran Perusahaan terhadap nilai perusahaan pada perusahaan yang terdaftar di Bursa Efek Indonesia (BEI) selama periode 2016? (2) Bagaimana pengaruh Ukuran Perusahaan terhadap nilai perusahaan pada perusahaan yang terdaftar di Bursa Efek Indonesia (BEI) selama periode 2016 jika dimoderasi dengan jumlah komite audit?

Tujuan dari penelitian ini adalah untuk mengetahui seberapa besar Ukuran Perusahaan berpengaruh terhadap nilai perusahaan pada perusahaan yang terdaftar di Bursa Efek Indonesia (BEI) selama periode 2016. Bagaimana pengaruhnya jika dimoderasi oleh keberadaan komite audit.

\section{Landasan Teori \\ Teori Agensi}

Masalah dasar dalam agency theory yaitu adanya konflik kepentingan atau konflik agensi (Sari, 2019). Teori Agensi menganalisis dan mencari solusi atas dua permasalahan yang muncul dalam hubungan antara "principal" (pemilik/pemegang saham) dan "agent" (manajemen puncak), yakni: 1) Agency problem muncul ketika (a) timbul konflik antara harapan atau tujuan pemilik/pemegang saham dan para direksi (top management), dan (b) para pemilik mengalami kesulitan ssuntuk memverifikasi apa yang sesungguhnya sedang dikerjakan manajemen. 2) Risk sharing problem yang muncul ketika pemilik dan direksi memiliki sikap yang berbeda terhadap risiko (Surjadi dan Tobing, 2016).

Untuk kepentingan pemilik itulah komite audit dibentuk dan salah satu cara yang dapat dilakukan oleh pemilik untuk memastikan bahwa manajemen mengelola perusahaan dengan baik adalah dengan mekanisme corporate governance yang tepat (Yanti, 2016; Patmawati, 2017; Eliana \& Wahyuni, 2019). Dengan mekanisme corporate governance yang tepat diharapkan manajemen akan dapat memenuhi tanggung jawabnya sehubungan dengan kepentingan pemilik. Komite audit memiliki peran penting dalam menjaga akuntabilitas perusahaan. Komite audit bertugas mengawasi dan memantau sistem pelaporan keuangan perusahaan dan proses audit internal dan eksternal untuk menghindari asimetri informasi yang menjadi salah satu permasalahan dalam teori keagenan (Surjadi \& Tobing,2016).

Semakin banyak anggota dalam suatu komite audit akan mempengaruhi independensi dari komite audit. Oleh sebab itu semakin banyak anggota komite audit maka akan meningkatkan independensi komite audit dan akan berpengaruh terhadap kualitas laporan keuangan perusahaan (Anggraini, 2013). Dengan begitu Komite Audit diharapkan mampu meningkatkan nilai perusahaan dan membantu pelaksanaan Good Coporate Governance. Selain itu keberadaan dan independensi komite audit dapat mengurangi konflik kepentingan yang ada pada teori keagenan dan meningkatkan nilai perusahaan dimata principal (Anggraini, 2013).

Ukuran perusahaan merupakan variabel yang berpotensi dan banyak digunakan untuk menjelaskan variasi pengungkapan dalam laporan tahunan perusahaan (Meiriasari, 2017). Hal ini jika dikaitkan dengan teori agensi, perusahaan besar yang memiliki biaya keagenan yang lebih besar akan mengungkapkan informasi yang lebih luas untuk mengurangi biaya keagenan tersebut (Putri et al., 2016) itu fenomena yang ada saat ini bahwa perusahaan yang besar menjadi sorotan baik oleh para investor maupun pemerintah bagaimana manajemen perusahaan mengelola usahanya, dengan struktur modal yang besar bagaimana dialokasikan untuk operasional perusahaan, perlakuan terhadap karyawan dan kepedulian terhadap lingkungan perusahaan dalam penelitian ini dijadikan variabel moderator karena ukuran perusahaan adalah salah satu kriteria yang dipertimbangkan oleh investor dalam strategi berinvestasi artinya ukuran perusahaan dapat mempengaruhi kekuatan pengaruh dari pengungkapan CSR dan Jumlah komite audit terhadap nilai perusahaan (Purwohandoko, 2017).

Peneliti menggunakan kapitalisasi pasar sebagai indikator ukuran perusahaan karena kapitalisasi pasar ini menggambarkan potensi pertumbuhan perusahaan yang bagus serta memiliki resiko yang rendah (Japlani, 2015). sehingga kapitalisasi pasar dapat dijadikan suatu ukuran besar kecilnya perusahaan dari potensi 
pertumbuhan dan tingkat kepercayaan investor dalam menginvestasikan dana yang ada. Perusahaan yang berukuran lebih besar cenderung memiliki public demand akan informasi yang lebih tinggi dibanding perusahaan yang berukuran lebih kecil. Alasan lain adalah perusahaan besar memiliki biaya keagenan yang lebih besar tentu akan mengungkapkan informasi yang lebih luas hal ini dilakukan untuk mengurangi biaya keagenan yang dikeluarkan. Berdasarkan pemaparan diatas dapat dibentuk hipotesis dari variabel variabel yangterkait dan saling berhubungan yaitu variabel ukuran perusahaan, jumlah komite audit dan nilai perusahaan, hipotesi dibentuk berdasarkan hubungan diantaranya sehingga hipotesis dalam menelitian ini adalah:

H1 = Ukuran Perusahaan Berpengaruh Terhadap Nilai Perusahaan.

$\mathrm{H} 2=$ Komite audit memoderasi Pengaruh Ukuran Perusahaan terhadap nilai perusahaan.

\section{Metodologi}

Metode analisis data yang digunakan adalah regresi linier Metode ini dipilih karena referensi menunjukan bahwa adanya kecocokan antara alat analisis dengan variabel yang diteliti. Pengujian Pengolahan dan analisis data dalam penelitian ini dilakukan dengan menggunakan SPSS yang terdiri dari uji residual, uji asumsi klasik, dan uji hipotesis. Populasi penelitian ini adalah seluruh perusahaan yang terdaftar di Bursa Efek Indonesia (BEI) yang memenuhi kriteria populasi antara lain: 1) perusahaan yang terdaftar di Bursa Efek Indonesia sampai tahun 2016, 2) telah mempublikasikan d Annual Report tahun 2016, 3) memiliki nilai Price Earning Ratio (PER) yang positif.

Tabel 1. Tabel Rincian Kategori Populasi

\begin{tabular}{|l|c|}
\hline \multicolumn{1}{|c|}{ Keterangan } & Jumlah \\
\hline $\begin{array}{l}\text { Total Perusahaan Terdaftar } \\
\text { Sampai Tahun 2016 }\end{array}$ & $\mathbf{5 2 9}$ \\
\hline $\begin{array}{l}\text { Perusahaan yang belum publikasi } \\
\text { annual report 2016 }\end{array}$ & $(51)$ \\
\hline $\begin{array}{l}\text { Perusahaan Memiliki Nilai EPS } \\
\text { Negatif }\end{array}$ & $(114)$ \\
\hline Total Populasi & $\mathbf{3 6 4}$ \\
\hline
\end{tabular}

Berdasarkan rincian kategori tersebut maka populasi dalam penelitian ini berjumlah 364 perusahaan. Dari populasi tersebut maka dapat ditentukan jumlah sampel yang akan diteliti dalam penelitian ini. Teknik pengambilan sampel menggunakan random sampling yaitu pemilihan sampel dengan acak, teknik pengambilan sampel tersebut adalah teknik yang lebih cocok dengan penelitian yang menggunakan analisis regresi berganda. Sampel dari penelitian ini adalah sebanyak 191 yang akan diambil secara acak dari populasi yang ada.

\section{Pembahasan \\ Hasil Uji Penelitian}

Pengujian hipotesis dalam penelitian ini sebelumnya harus dilakukan terlebih dahulu analisis statistik terhadap data yang telah diperoleh sebelumnya.

\section{Persamaan Regresi 1}

Berikut ini adalah persamaan regresi 1:

$$
\mathrm{Y}=\mathrm{a}+\mathrm{b}_{1} \mathrm{MV}+\varepsilon_{1}
$$

Hasil hipotesis untuk persamaan regresi 1 yang telah diolah dengan bantuan program SPSS dapat dilihat pada dua uji berikut ini:

\section{Hasil Uji Hipotesis \\ Uji F}

Hasil uji F dilakukan untuk melihat pengaruh secara simultan atau bersama variabel bebas yaitu ukuran Perusahaan dan komite audit (AC) terhadap nilai perusahaan (PER) pada perusahaan yang terdaftar di Bursa Efek Indonesia. Hasil uji F tersebut dapat dilihat pada tabel 2 berikut:

Tabel 2. Tabel Hasil Uji F

\begin{tabular}{|l|l|l|l|}
\hline \multicolumn{2}{|c|}{ Sum of Square } & \multicolumn{2}{c|}{ Signifikan } \\
\hline $\begin{array}{l}\text { Regresion } \\
\text { Of }\end{array}$ & 1453,285 & 4.844 & $.029^{\mathrm{a}}$ \\
\hline
\end{tabular}

Dari tabel 2 di atas dapat dilihat bahwa $F_{\text {hitung yaitu }}$ sebesar 4.844 dengan nilai Sig. yaitu 0.000. Pengujian hipotesis dalam penelitian ini dengan membandingkan nilai $F_{\text {hitung }}$ dan $F_{\text {tabel }}$ taraf signifikansi yaitu $5 \%$ sehingga didapat nilai $F_{\text {tabel }}$ yaitu sebesar 3,89. Berdasarkan hasil tersebut dapat dilihat bahwa nilai $F_{\text {hitung yaitu sebesar }}$ 4,844 lebih besar dari nilai $F_{\text {tabel }}$ yaitu sebesar 3,89. Artinya variabel independen yaitu market value berpengaruh Signifikan secara simultan terhadap variabel dependen nilai perusahaan (PER) pada perusahaan yang terdaftar di Bursa Efek Indonesia.

\section{Hasil Uji T}

Hasil uji t dilakukan untuk melihat pengaruh secara parsial atau sendiri variabel bebas yaitu Ukuran perusahaan terhadap nilai perusahaan pada perusahaan yang terdaftar di Bursa Efek Indonesia. Hasil uji t tersebut dapat dilihat pada tabel 3 berikut:

Tabel 3. Tabel Hasil Uji T

\begin{tabular}{|l|l|l|}
\hline \multicolumn{1}{|c|}{ T } & \multicolumn{3}{c|}{ Sig } \\
\hline (Constant) & - & .3 \\
MV & 1.0 & 00 \\
& 40 & \\
\hline & 2.2 & .0 \\
& 01 & 29 \\
\hline
\end{tabular}

Pengujian hipotesis dalam penelitian ini dilakukan dengan membandingkan nilai thitung dan $\mathrm{t}_{\text {tabel. }}$. Dimana nilai tabel berdasarkan $(\mathrm{df}=\mathrm{n}-2) \mathrm{df}=191-2$ yaitu 189 dan taraf signifikansi yaitu 5\% sehingga didapat nilai tabel yaitu 
sebesar 1,652 Pada tabel 3 di atas dapat dilihat bahwa nilai thitung adalah senilai 2,201 dapat dijelaskan bahwa Market Value (MV) berpengaruh secara signifikan terhadap nilai perusahaan, ditunjukkan dengan nilai thitung sebesar 2,201 yang lebih besar dari nilai tabel yaitu sebesar 1,652.

\section{Hasil Uji Interaksi Moderasi}

Pada persamaan regresi 2 dengan uji interaksi hasil hipotesis dapat dilihat yitu dengan meambandingkan hasil R squere dari persamaan satu dan Persamaan 2 dimana persamaan 1 adalah $\mathrm{Y}=\mathrm{Y}=\mathrm{a}+\mathrm{b}_{1} \mathrm{MV}+\varepsilon_{1}$ dan Persamaan 2 adalah $=\mathrm{Y}=\mathrm{a}+\mathrm{b}_{1} \mathrm{MV}+\mathrm{b}_{2} \mathrm{AC}+\mathrm{b}_{3}$ $\mathrm{MV}^{*} \mathrm{AC}+\varepsilon_{1}$ hasil terlihat pada tabel berikut:

\section{Tabel 4. Hasil Uji Interaksi Persamaan 1} Model Summary

\begin{tabular}{lr|r|r|r} 
Model & $\mathrm{R}$ & $\begin{array}{c}\mathrm{R} \\
\text { Square }\end{array}$ & $\begin{array}{c}\text { Adjusted R } \\
\text { Square }\end{array}$ & $\begin{array}{l}\text { Std. Error of } \\
\text { the Estimate }\end{array}$ \\
\hline 1 & $.158^{\mathrm{a}}$ & .025 & 0.20 & $\begin{array}{r}17.32182742 \\
0000000\end{array}$ \\
\hline
\end{tabular}

a. Predictors: (Constant), MPV

Tabel 5. Tabel Hasil Uji Interaksi Persamaan 2

\begin{tabular}{ll|r|r|r} 
& \multicolumn{4}{c}{ Model Summary } \\
Model & R & R Square & $\begin{array}{c}\text { Adjusted R } \\
\text { Square }\end{array}$ & $\begin{array}{r}\text { Std. Error of } \\
\text { the Estimate }\end{array}$ \\
\hline 1 & $.186^{\mathrm{a}}$ & .035 & .019 & $\begin{array}{r}17.32879410 \\
0000000\end{array}$ \\
\hline
\end{tabular}

a. Predictors: (Constant), MV*AC

Dari hasil uji interaksi kedua persamaan tersebut dapat dilihat nilai $\mathrm{R}$ squere pada persamaan 2 dapat dilihat pada table 5 lebih besar yaitu sebesar 0,035 dari pada pada persamaan 1 dapat dilihat pada table 4yaitu sebesar 0,025 artinya keberadaan komite audit mampu memoderasi atau memperkuat pengaruh pengungkapan Ukuran Perusahaan terhadap nillai perusahaan.

\section{Pembahasan Hasil Penelitian}

Pengaruh Pengungkapan Ukuran Perusahaan Terhadap Nilai Perusahaan

Ukuran Perusahaan merupakan akar dari pengakuan bahwa bisnis perusahaan diminati Hasil Pengujian Hipotesis Uji F Secara Simultan Ukuran perusahaan berpengaruh Positif dan signifikan terhadap nilai perusahaan.

Berdasarkan Hasil Uji T Secara Persial Ukuran perusahaan berpengaruh secara signifikan terhadap nilai perusahaan, ditunjukkan dengan nilai thitung sebesar 2,201 yang lebih besar dari nilai tabel yaitu sebesar 1,652. Hal ini membuktikan bahwa diindonesia fakta bahwa investor telah melihat nilai suatu perusahaan dari ukuran perusahaanya . Hasil Penelitian ini mendukung hasil penelitian yang pernah dilakukan menurut (Perusahaan \& Novari, 2016) Ukuran perusahaan dinyatakan berhubungan positif dan signifikan terhadap nilai perusahaan (Angga Pratama \& Wiksuana, 2018) yang menyatakan bahwa ukuran perusahaan berpengaruh positif dan signifikan terhadap nilai perusahaan. Dan bertentangan (Indriyani, 2017) menemukan bahwa ukuran perusahaan mempunyai nilai negatif dan signifikan terhadap nilai perusahaan.hasil penelitian ini dapat menjadi referensi berikutnya dengan hasil positif signifikan.

Moderasi Komite Audit pada Pengaruh Pengungkapan Ukuran Perusahaan terhadap Nilai Perusahaan

Berdasarkan hasil uji interaksi pada persamaan pertama dan kedua jumlah komite audit perusahaan dapat memoderasi dengan memperkuat pengaruh Ukuran Perusahaan dengan nilai perusahaan. Hal ini sejalan dengan teori agency dan bahwa perusahaan yang memiliki komite audit sesuai standart akan menguragi asimetri informsi bagi perusahaan dengan kapitalisasi yang tinggi dan akan semakin meningkatkan nilai perusahaan..

\section{Kesimpulan}

Berdasarkan hasil analisis dan pembahasan pada bab sebelumnya, maka kesimpulan yang dapat ditarik dari penelitian ini adalah: Variabel Ukuran perusahaan memiliki pengaruh yang signifikan terhadap Nilai Perusahaan pada perusahaan yang terdaftar di Bursa Efek Indonesia. Variabel Komite Audit (AC) dapat memoderasi dengan memperkuat pengaruh ukuran perusahaan terhadap Nilai Perusahaan (PER).

\section{Daftar Pustaka}

Anggraeni. (2012). The Influence of Firm's Size, Growth, and Profitability on Firm Value with Capital Structure as the Mediator: A Study on the Agricultural Firms Listed in the Indonesian Stock Exchange. International Journal of Economics and Finance, $9(8)$,

103. https://doi.org/10.5539/ijef.v9n8p103

Angga Pratama, A. B., \& Wiksuana, I. G. B. (2018). Pengaruh Firm Size Dan Profitabilitas Terhadap Nilai Perusahaan Dengan Struktur Modal Sebagai Variabel Mediasi. E-Jurnal Ekonomi Dan Bisnis Universitas Udayana, 5, 1289. https://doi.org/10.24843/eeb.2018.v07.i05.p03

Eliana, E., \& Wahyuni, D. (2019). Pengaruh Implementasi Corporate Governance terhadap Efisiensi Bank Umum di Indonesia. Jurnal Ilmiah Ekonomi Global Masa Kini, 10(2), 111-118.

Herlianto, Didit.2013.Manajemen Investasi Plus Jurus Mendeteksi Investasi Boong.Yogyakarta:Gosyen Publishing. (n.d.).

Indriyani, E. (2017). Pengaruh Ukuran Perusahaan dan Profitabilitas Terhadap Nilai Perusahaan. Akuntabilitas, 10(2), 333-348. https://doi.org/10.15408/akt.v10i2.4649

Japlani, A. (2015). Apakah Ukuran Itu Penting? Jurnal Akuisisi, 11(1), 1-21.

Kanwal, M., Khanam, F., Nasreen, S., \& Hameed, S. (2013). Impact of corporate social responsibility on the firm 's financial performance. Journal of Business and Management (IOSR-JBM), 14(5), 67- 
74. https://doi.org/10.1145/2925995.2926045

Meiriasari, V. (2017). Pengaruh Corporate Governance, Kepemilikan Keluarga, Kepemilikan Institusional Dan Ukuran Perusahaan (Firm Size) Terhadap Biaya Utang. Jurnal Ilmiah Ekonomi Global Masa Kini, $8(1), 28-34$

Novari, P. M. (2016). PROFITABILITAS TERHADAP NILAI PERUSAHAAN PADA SEKTOR Fakultas Ekonomi dan Bisnis Universitas Udayana (Unud), Bali , Indonesia PENDAHULUAN Mempertahankan kontinuitas perusahaan adalah elemen penting yang harus dipertahankan oleh perusahaan, terutama men. 5(9), 5671-5694.

Patmawati, P. (2017). Pengaruhcorporate Social Responsibility Disclosure dan Good Corporate Governance terhadap Nilai Perusahaan dengan Kinerja Keuangan sebagai Variabel Intervening. Jurnal Ilmiah Ekonomi Global Masa Kini, 8(1), 4658.

Puteuri, P. A., \& Rohman, A. (2012). Analisis Pengaruh Investment Opportunity Set (Ios) Dan Mekanisme Corporate Governance Terhadap Kualitas Laba Dan Nilai Perusahaan. Analisis Pengaruh Investment Opportunity Set (Ios) Dan Mekanisme Corporate Governance Terhadap Kualitas Laba Dan Nilai Perusahaan, 1(1), 24-37.

Putri, A. K., Sudarma, M., \& Purnomosidhi, B. (2016). Pengaruh Corporate Social Responsibility terhadap Nilai Perusahaan dengan Ukuran Perusahaan dan Jumlah Dewan Komisaris sebagai Variabel Pemoderasi ( Studi pada Perusahaan Manufaktur yang terdaftar Bursa Efek Indonesia ). Jurnal Aplikasi Manajemen, 344, 1-15.

Sari, R. (2019). Moderasi Jumlah Komite Audit atas Pengaruh Pengungkapan Corporate Social Responsibility terhadap Nilai Perusahaan. Jurnal Ilmiah Ekonomi Global Masa Kini, 10(2), 119-123.

Surjadi, C., \& Tobing, R. L. (2016). GOOD CORPORATE GOVERNANCE TERHADAP NILAI PERUSAHAAN ( Studi pada PerusahaanPerusahaan Emiten yang Terdaftar Pada LQ 45 Periode Agustus 2014 s / d Januari 2015 ). Jurnal Manajemen Bisnis, 11(2), 69-78.

Susanto,Azhar.2013 Sistem Informasi Akuntansi.Bandung:Lingga jaya. (n.d.).

S Purwohandoko (2017). Good Corporate Governance. 110

Yanti, D. (2016). Pengaruh Kualitas Audit, Kinerja Keuangan, dan Ukuran Perusahaan terhadap Pengungkapan Good Corporate Governance pada Perusahaan LQ 45 yang Terdaftar di Bursa Efek Indonesia. Jurnal ilmiah ekonomi global masa kini, 6(1), 1-9. 